\title{
Decision Support System for Community Housing Subsidy Recipients
}

\author{
Adhi Nugraha ${ }^{a *}$, Alvian Widianto ${ }^{b}, M$. Irfan $^{b}$, M. Nasar ${ }^{b}$, Merinda Lestandy $^{c}$ \\ a Jurusan Teknik Industri, Fakultas Teknik, Universitas Muhammadiyah Malang, Indonesia \\ Jl. Raya Tlogomas No. 246 Malang, Jawa Timur, Indonesia \\ b Jurusan Teknik Elektro, Fakultas Teknik, Universitas Muhammadiyah Malang, Indonesia \\ Jl. Raya Tlogomas No. 246 Malang, Jawa Timur, Indonesia \\ c Jurusan D3 Teknik Elektronika, Fakultas Teknik, Universitas Muhammadiyah Malang, Indonesia \\ Jl. Raya Tlogomas No. 246 Malang, Jawa Timur, Indonesia \\ *Corresponding author: adhinugraha@umm.ac.id
}

\section{ARTICLE INFO}

\section{Article history}

Received December 12, 2019

Revised February 21, 2020

Accepted February 25, 2020

Available Online February 28, 2020

\section{Keywords}

Housing subsidy recipient

Decision support system

Pairwise Comparison

AHP

\begin{abstract}
Human needs consist of primary, secondary, and tertiary needs. In primary needs, the house is one of the most critical primary needs in supporting one's life. However, not all residents in Indonesia can meet these needs. Therefore, the government provides subsidized housing ownership programs for people with low income. This study aims to propose a decision support system in determining the proper housing subsidy recipients. The method used in weighting is Analytic Hierarchy Process (AHP). Previous research was still limited to the selection of subsidized housing for developers and potential buyers. This method is projected to provide results in the form of a priority sequence of alternative solutions based on test results. The results were considered capable of providing a better solution for selecting prospective recipients of the housing subsidy program.
\end{abstract}

This is an open-access article under the CC-BY-SA license.

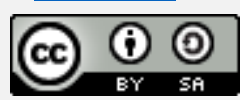

\section{Introduction}

House is an essential primary need for humans. People think that owning a house is a long-term investment [1][2]. The higher demand for housing has an impact on the higher house prices. This phenomenon decreases the purchasing power of people with income below the average. This problem has prompted the government to create a subsidized housing program. However, the implementation of the subsidized housing program often does not go according to plan. Identification and accuracy of recipients are the main problematic factors [3]. Most of the houses in the subsidy program were occupied by upper to middle-class owners. The main target of subsidized recipients is the lowermiddle class. An appropriate system for determining subsidy recipients is needed to assist in determining the recipient of subsidies. Therefore, the government is urged to find the proper procedure in determining the recipient of the subsidy. The use of the proper method can provide an alternative in making decisions. One alternative that can be developed is 
using a Decision Support System (DSS) [4]. DSS functions to solve problems and communicate problems with structured situations [5][6]. DSS can summarize information, patterns, and trends using analytical models. DSS systems can also help identify, solve problems, and make decisions to find the best alternative [7] [8].

Several previous studies have been very limited in discussing DSS issues in the housing sector as well as in terms of subsidy recipients. Nasibu [1] solved selecting mortgages using the Analytic Hierarchy Process (AHP) method. Oei [2] used the AHP and Borda methods in solving the DSS for home purchases. Another study was conducted by Hudaya [9], who discussed determining the eligibility of subsidies using the Adaptive Neuro-Fuzzy Inference System method. A DSS system based on AHP was proposed by Sarwindah and Marini [10] for consumers who chose subsidized housing. Simanjorang, et al. [11] developed an analysis of the DSS for needy rice subsidy recipients. Siregar, et al. [12] implemented a DSS for subsidized housing selection using the Weighted Aggregated Sum Production Assessment Method. Even the DSS based on the Simple Multi-Attribute Rating Technique has also been proposed by Saputra and Mawartika [6] in choosing housing.

Several other studies have also been investigated. Mahendra and Putri [13] used the AHP method for the house selection process. House selection is faster because it is assisted by Expert Choice Software. Ardiyanto, et al. [14] applied web-based AHP to the housing selection process. Primanda, et al. [15] utilized AHP and Simple Additive Weight to select the best cost. AHP was then used by Rais [16] for the determination of strategic housing locations. Based on previous research, most studies generally discuss the problem of house selection. To the researchers' knowledge, there has been no research discussing DSS in the selection of recipients of subsidized housing assistance. Therefore, this study proposes a DSS to provide a solution to selecting subsidized housing recipients.

In DSS, the popular method used is AHP [2][17]. AHP method is carried out based on Pairwise comparisons and a hierarchy of criteria [18]. This method is chosen because this method can solve complex problems with structured procedures. AHP aims to distribute subsidized housing assistance more targeted to the middle to lower economic class. The AHP method is implemented with the PHP programming language using three criteria: family dependents, income, and occupation. PHP programming is implemented to produce the right decision support application system for web-based subsidized home subsidy receivers [11][19]. With the development of this DSS, it is hoped that housing subsidy recipients' selection process will be more straightforward and more targeted.

This paper's composition is presented as follows: Research method and data collection are presented in section 2 . Results and discussion, as well as system testing, are presented in section 3. Meanwhile, section 4 discusses the conclusions of the entire study.

\section{Methods}

\subsection{Problem Analysis}

At present, the process of allocating subsidized housing from the government is still not optimal. The selection process is considered to be unable to reach the people who need it. Many houses should be allocated to the middle to lower economic class but owned by the middle and upper economic classes. This case occurred because of the lack of data management carried out by the developers and government. Therefore, a DSS is needed so that subsidy recipients are more targeted. This subsidized housing selection process is

Please cite this article as: Nugraha, A., Widianto, A. ., Irfan , M. ., Nasar , M., \& Lestandy, M. . (2020). Decision Support System for Community Housing Subsidy Recipients. Jurnal Teknik Industri, 21(1), 104-114. https://doi.org/10.22219/JTIUMM.Vol21.No1.104-114 
a case study involving a variety of complex instruments. Seeing the urgency of this problem, a DSS is needed to help make appropriate decisions. AHP method is the proper method to be applied in problems with multi-object properties such as this problem [8]. This method can solve problems that have many alternatives and criteria that produce the best decisions.

\subsection{AHP Diagram Block}

In this subsection, this study proposes a block diagram to illustrate the pattern of the proposed DSS. The initial stage is determining criteria and identifying data. Some of the data required are National Identity Card Number, No-House Owning Certificate, Letter of Assistance Recipient, Taxpayer Identification Number, and Family Card Number. If the participant does not meet the initial qualifications, the participant cannot continue to the next stage. The second stage is filling out forms related to the criteria for selecting beneficiaries. In stage 2 , several criteria and sub-criteria are used concerning the selection of housing subsidies. The criteria used are Family Dependents, which have five sub-criteria, income has three sub-criteria, and occupation has four sub-criteria. A more detailed description regarding the AHP process diagram can be seen in Fig. 1.

If the input process is correct and the applicable provisions can execute the AHP calculation process. The final result of the calculation is the ranking of potential beneficiaries.

\subsection{Data Collection}

The data processed in this study were derived from a questionnaire related to the process of selecting beneficiaries. The data were then converted into a Pairwise Comparison table by the provisions of Saaty [18]. For more apparent data, see Table 1 to Table 4.

\begin{tabular}{llll} 
& \multicolumn{2}{l}{ Table 1. Pairwise Comparison Criteria } & \\
\hline CRITERIA & $\begin{array}{l}\text { Family } \\
\text { Dependents }\end{array}$ & Income & Occupation \\
\hline Family Dependents & 1 & $1 / 5$ & 4 \\
\hline Income & 5 & 1 & 5 \\
\hline Occupation & $1 / 4$ & $1 / 5$ & 1 \\
\hline
\end{tabular}

Table 2. Pairwise Comparison Sub-Criteria for Family Dependents

\begin{tabular}{llllll}
\hline Family Dependents & $>3$ Child & 3 Child & 2 Child & 1 Child & $\begin{array}{l}\text { Have no } \\
\text { Children }\end{array}$ \\
\hline$>3$ Child & 1 & 3 & 5 & 5 & 7 \\
\hline 3 Child & $1 / 3$ & 1 & 3 & 3 & 5 \\
\hline 2 Child & $1 / 5$ & $1 / 3$ & 1 & 2 & 3 \\
\hline 1 Child & $1 / 5$ & $1 / 3$ & $1 / 2$ & 1 & 2 \\
\hline Have no Children & $1 / 7$ & $1 / 5$ & $1 / 3$ & $1 / 2$ & 1 \\
\hline
\end{tabular}




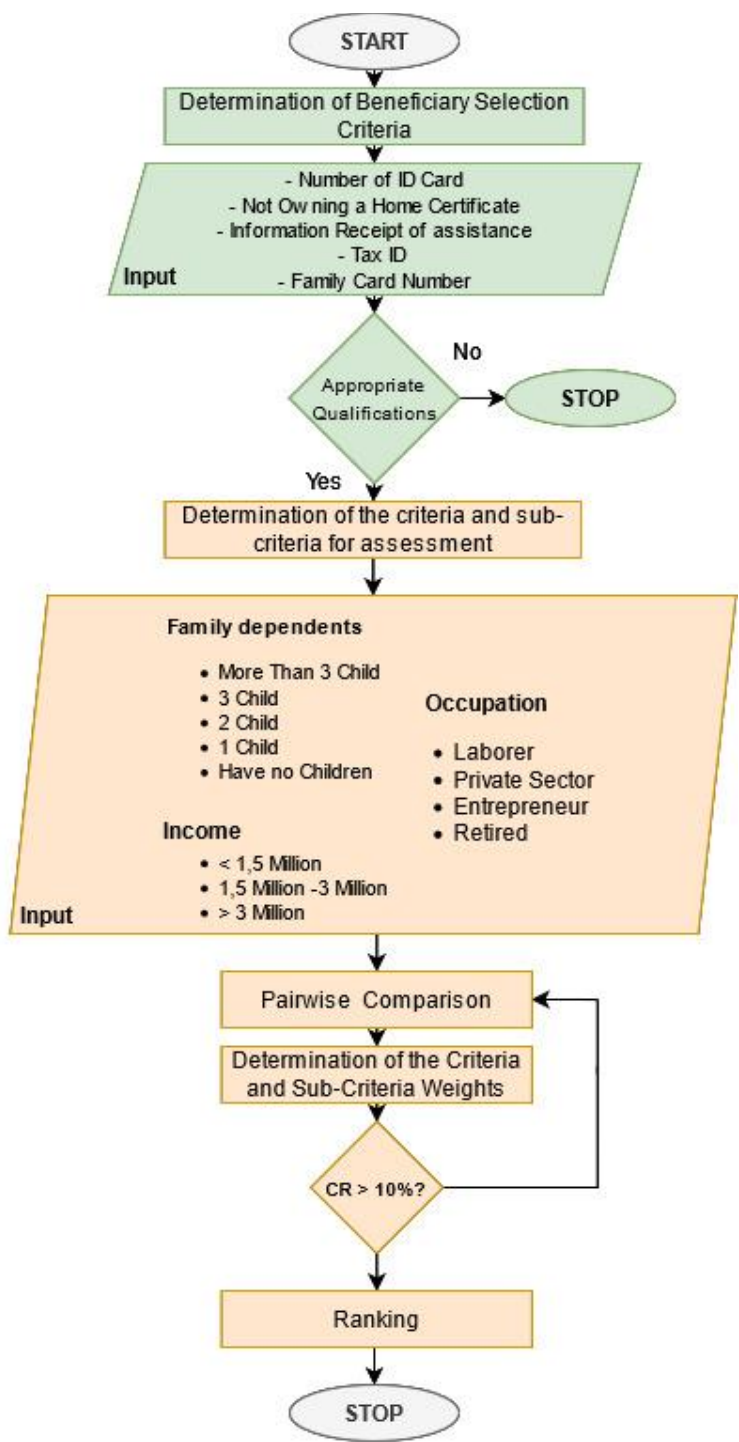

Fig. 1. Block Diagram of Analytic Hierarchy Process (AHP)

Table 3. Pairwise Comparison Sub-Criteria Family Income (in IDR)

\begin{tabular}{llll}
\hline Income & $<1.5$ Million & $1.5-3$ Million & $>3$ Million \\
\hline$<1,5$ Million & 1 & 2 & 3 \\
\hline $1,5-3$ Million & $1 / 2$ & 1 & 2 \\
\hline$>3$ Million & $1 / 3$ & $1 / 2$ & 1 \\
\hline
\end{tabular}

Table 4. Pairwise Comparison Sub-Criteria Family Occupation

\begin{tabular}{lllll} 
Occupation & Laborer & Private Sector & Entrepreneur & Retired \\
\hline Laborer & 1 & 3 & 3 & 5 \\
\hline Private Sector & $1 / 3$ & 1 & 2 & 3 \\
\hline Entrepreneur & $1 / 3$ & $1 / 2$ & 1 & 2 \\
\hline Retired & $1 / 5$ & $1 / 3$ & $1 / 2$ & 1
\end{tabular}




\section{Results and Discussion}

This section describes implementing and testing the DSS for subsidized housing recipients using the AHP method. This section consists of program implementation, the weighting of criteria and sub-criteria, and system testing.

\subsection{Program Implementation}

After the DSS was created, the next step was to implement a web-based application. Fig. 2 describes the user's home page. The homepage display has a menu of profiles (personal identity), documents (requirements for submitting subsidized housing), criteria (system support using the AHP method), and announcements (results of calculations carried out with several alternative recipients).

(i) localhost/alvian/index.php/user/document

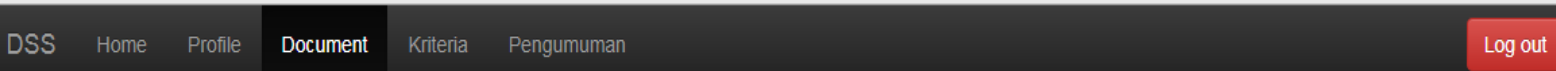

\begin{tabular}{l} 
Document! \\
KTP \\
\hline 5598099094394 \\
Surat Keterangan Tidak Memiliki Rumah \\
\hline $747 / 4545 / 2019$ \\
Belum Pernah Menerima Bantuan \\
ya@ Tidak \\
Memiliki Nomor Pokok Wajib Pajak (NPWP) \\
\hline 87.959856845 \\
\hline Memiliki Kartu Keluarga \\
\hline 35082394894521 \\
\hline
\end{tabular}

Fig. 2. User Home Page Eligibility (in Indonesian version)

The further stage was to fill in the user assessment page based on the existing selection criteria. There was a menu of options regarding Family, Income, and Occupation of Dependents on this page. Each of these menus has a choice of sub-criteria used. Users were asked to choose according to circumstances. This procedure is described in Fig. 3.

\subsection{Weights of Criteria and Sub-Criteria}

Using the web-based AHP program that has been created, this study determined each criterion and sub-criteria's weight. The results of weighting the criteria and subcriteria can be seen in Fig. 4 to Fig. 7. 
(i) localhost/alvian/index.php/user/document

Silahkan mengisi data sesuai dengan keadaan yang sebenamya. Mengalami kendala saat pengisian? Silahkan hubungi Kami

Tanggungan Keluarga

- Lebih dari 3 Anak

3 Anak

2 Anak

1 Anak

Tidak Memiliki Anak
Pendapatan

- $<1,5$ Juta

1,5 Juta sampai dengan 3 Juta

$>3$ Juta

Fig. 3. User Selection Criteria Determination page (in Indonesian version)

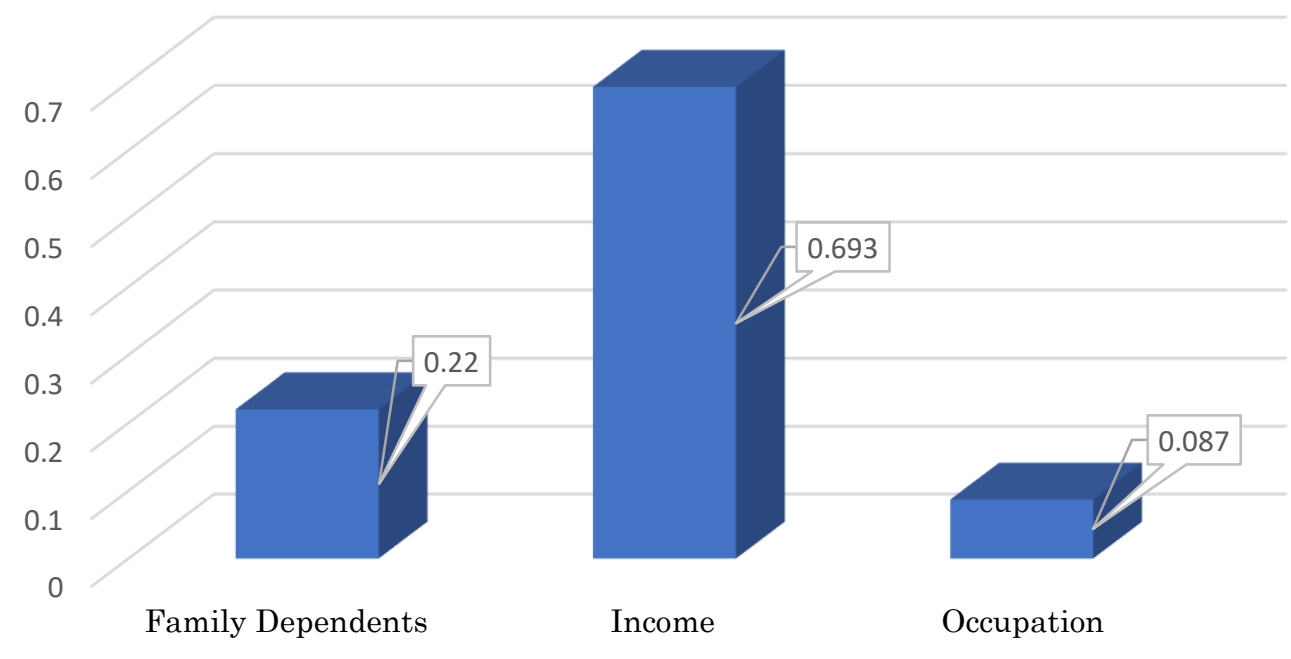

Fig. 4. The Weight of the Selection Criteria for House Subsidy Participants

Fig. 4 shows that the "income" criterion was the criterion with the heaviest weight. The second rank was occupied by the criterion "Family dependents" and in the last rank was occupied by the criterion "Employment/Occupation". This result shows that income is the main criterion in selecting recipients of subsidized housing assistance. 


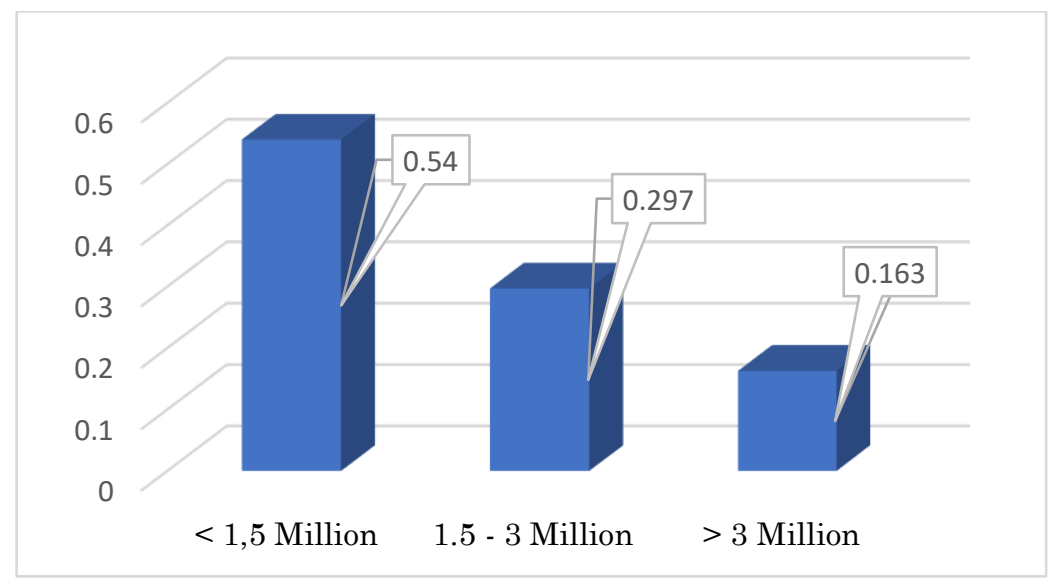

Fig. 5. Weights of Income Sub-Criterion

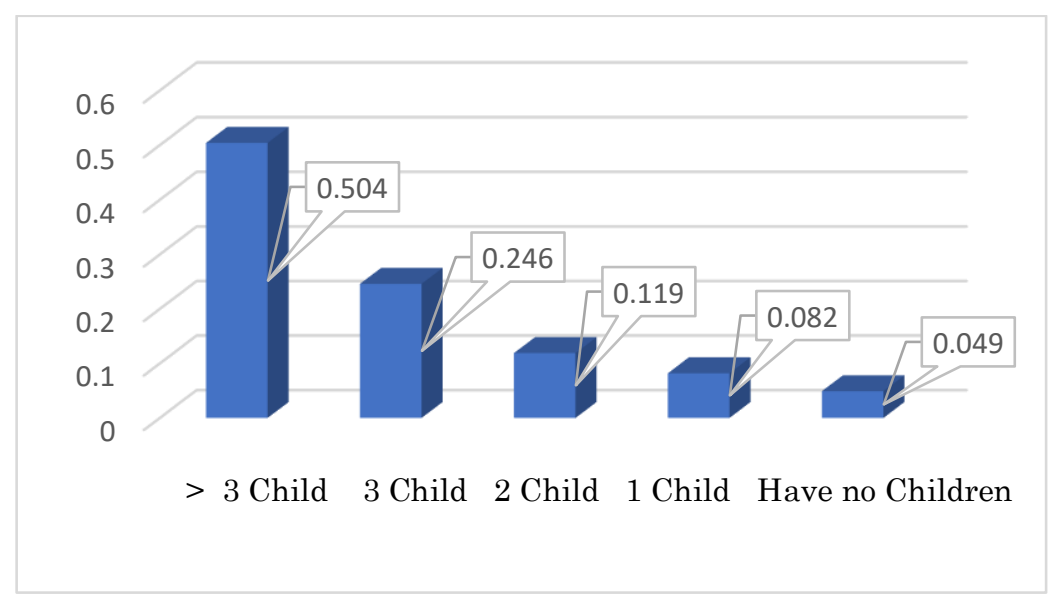

Fig. 6. Weight of Family Dependents Sub-Criterion

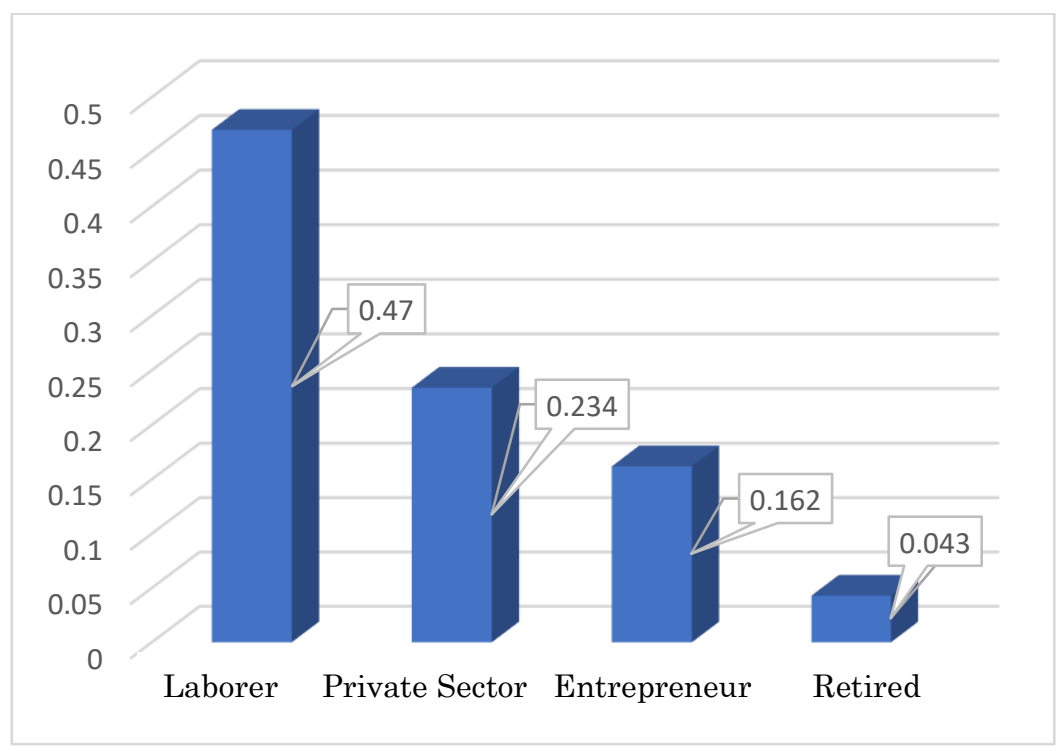

Fig. 7. Weight of Occupation Sub-Criterion 
Based on Fig. 5 to Fig. 7, subsidized assistance recipients were prioritized for communities with less than 1.5 million incomes with dependent children of more than 3 . In addition, the selected occupation as a laborer was prioritized as a recipient. This of course illustrates that the target of the government is those who need assistance.

\subsection{Testing}

The application testing phase was carried out to determine the accuracy of the DSS design that has been utilized. This test required identity data. Identity data for DSS testing is presented in

Table 5. Furthermore, the DSS determined alternative rankings as presented in Table 6.

Table 5. List of Prospective Housing Subsidy Recipients

\begin{tabular}{llccc}
\hline No & Alternative Name & Family Dependents & Income & Occupation \\
\hline 1 & Anggi saputra & $>3$ & $<1,5$ Million & Laborer \\
2 & Dimas pamungkas & 3 & $<1,5$ Million & Laborer \\
3 & Baruna putra & 1 & $>3$ Million & Private Sector \\
4 & Wahyu wirawan & 2 & $<1,5$ Million & Laborer \\
5 & Dino hidayat & 2 & $>3$ Million & Private Sector \\
6 & Farid darmawan & 1 & $<1,5$ Million & Laborer \\
7 & Dani alves & $>3$ & $1,5-3$ Million & Retired \\
8 & Budi santoso & 3 & $1,5-3$ Million & Retired \\
9 & Jefri amin & 3 & $>3$ Million & Private Sector \\
10 & Rizki darmawan & 3 & $1,5-3$ Million & Entrepreneur \\
11 & Ringgo ferdinand & 2 & $1,5-3$ Million & Retired \\
12 & Iklil malahin & 2 & $>3$ Million & Retired \\
13 & diko pratama & 1 & $1,5-3$ Million & Retired \\
14 & Alvian widianto & $>3$ & $>3$ Million & Private Sector \\
15 & Delliar khafid & $>3$ & $>3$ Million & Retired \\
\hline
\end{tabular}

Table 6. Determination of Alternative Ranking

\begin{tabular}{llllll}
\hline Alternative Name & $\begin{array}{l}\text { Family } \\
\text { Dependents }\end{array}$ & Income & Occupation & Total & Rank \\
\hline Anggi saputra & $0.22^{*} 0.504$ & $0.693^{*} 0.54$ & $0.087^{*} 0.47$ & 0.52599 & 1 \\
Dimas pamungkas & $0.22^{*} 0.246$ & $0.693^{*} 0.54$ & $0.087^{*} 0.47$ & 0.46923 & 2 \\
Wahyu wirawan & $0.22^{*} 0.119$ & $0.693^{*} 0.54$ & $0.087^{*} 0.234$ & 0.44129 & 3 \\
Farid darmawan & $0.22^{*} 0.082$ & $0.693^{*} 0.54$ & $0.087^{*} 0.47$ & 0.43315 & 4 \\
Dani alves & $0.22^{*} 0.504$ & $0.693^{*} 0.297$ & $0.087^{*} 0.043$ & 0.320442 & 5 \\
Budi santoso & $0.22^{*} 0.246$ & $0.693^{*} 0.297$ & $0.087^{*} 0.043$ & 0.263682 & 8 \\
Rizki darmawan & $0.22^{*} 0.246$ & $0.693^{*} 0.297$ & $0.087^{*} 0.162$ & 0.274035 & 7 \\
Ringgo ferdinand & $0.22^{*} 0.119$ & $0.693^{*} 0.297$ & $0.087^{*} 0.043$ & 0.274035 & 6 \\
Diko pratama & $0.22^{*} 0.082$ & $0.693^{*} 0.297$ & $0.087^{*} 0.043$ & 0.227602 & 10 \\
Alvian widianto & $0.22^{*} 0.504$ & $0.693^{*} 0.163$ & $0.087^{*} 0.234$ & 0.244197 & 9 \\
Delliar khafid & $0.22^{*} 0.504$ & $0.693^{*} 0.163$ & $0.087^{*} 0.043$ & 0.22758 & 11 \\
Iklil malahin & $0.22^{*} 0.119$ & $0.693^{*} 0.163$ & $0.087^{*} 0.043$ & 0.14288 & 15 \\
Jefri amin & $0.22^{*} 0.246$ & $0.693^{*} 0.163$ & $0.087^{*} 0.043$ & 0.187437 & 12 \\
Dino hidayat & $0.22^{*} 0.119$ & $0.693^{*} 0.163$ & $0.087^{*} 0.234$ & 0.159497 & 13 \\
Baruna putra & $0.22^{*} 0.082$ & $0.693^{*} 0.163$ & $0.087^{*} 0.043$ & 0.151357 & 14 \\
\hline
\end{tabular}


Based on Table 6. the results of the subsidy acceptance test are represented in Fig. 8. The test is used to select seven primary candidates for subsidized housing recipients.

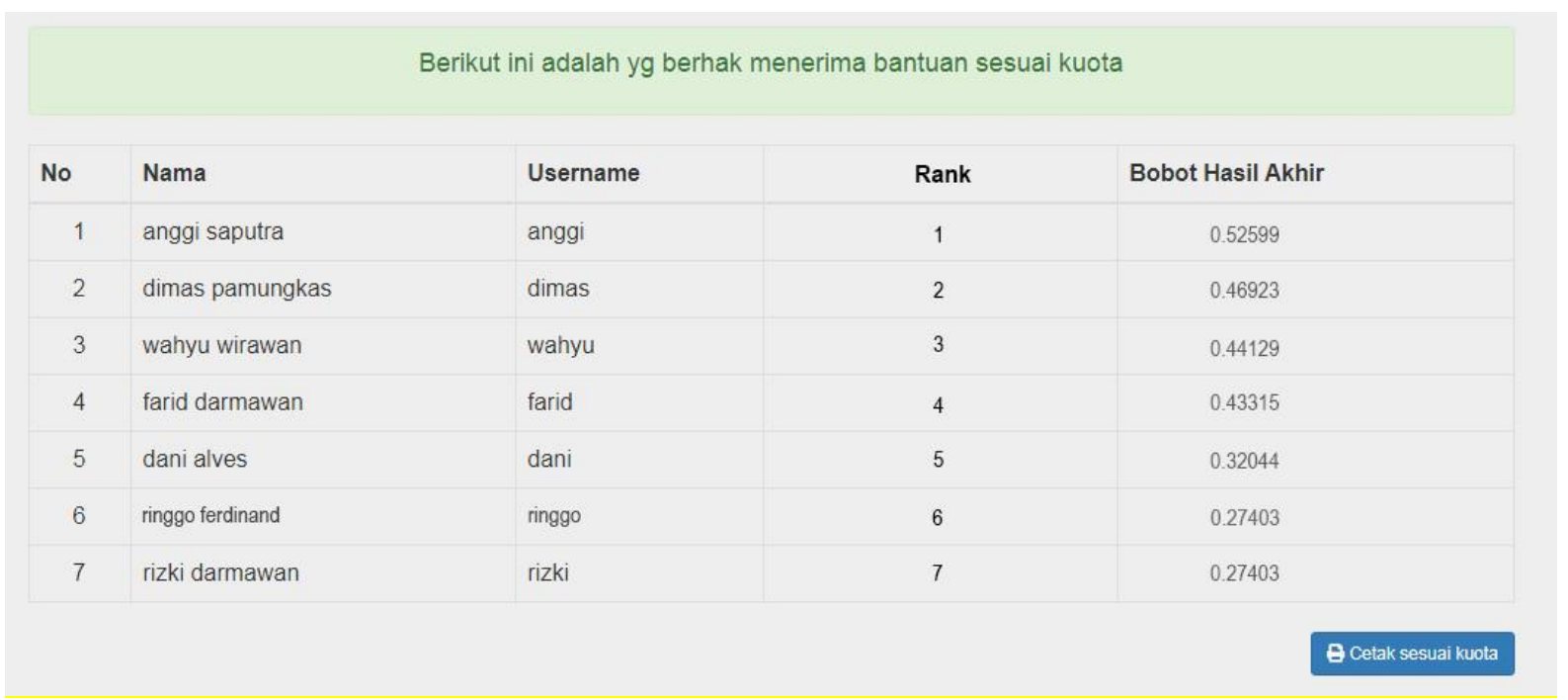

Fig. 8. Results of the ranking of subsidy recipients (in Indonesian version)

\section{Conclusion}

This study discusses the DSS in the selection of housing subsidies. This study implemented the Analytic Hierarchy Process (AHP) method based on the web. The results showed that income was the main criterion in selecting subsidized housing recipients, followed by family dependents and occupation criteria. The results also suggested that the DSS could be applied in the selection of subsidized housing assistance recipients. The future researcher suggests that it is necessary to consider other relevant criteria to select subsidized housing recipients. Furthermore, the characteristics of the information on the selection of subsidized housing recipients need to be considered in a fuzzy environment.

\section{Acknowledgment}

The author would like to send his gratitude to Universitas Muhammadiyah Malang (UMM) for the full support to conduct this study. His next gratitude is delivered to the Department of Industrial Engineering-Optimizing Laboratory-for for allowing its facilities to be used in the research conduct.

\section{References}

[1] I. Z. Nasibu, "Penerapan metode AHP dalam sistem pendukung keputusan penempatan karyawan menggunakan aplikasi Expert Choice," Jurnal Pelangi Ilmu, vol. 2, pp. 1-14, 2009. http://ejurnal.ung.ac.id/index.php/JPI/article/view/599.

[2] S. Oei, "Group Decision Support System Untuk Pembelian Rumah Dengan Menggunakan Analytical Hierarchy Process (AHP) dan Borda," in Seminar 
Nasional Informatika (SEMNASIF), $\quad 2015, \quad$ pp. $\quad 1-8$. http://www.jurnal.upnyk.ac.id/index.php/semnasif/article/view/961.

[3] R. Kuswandhie and Y. Primadasa, "Penggabungan Metode MEC dan AHP dalam Penentuan Bantuan Rumah Tidak Layak Huni," Techno. Com, vol. 18, pp. 134-144, 2019. https://doi.org/10.33633/tc.v18i2.2268.

[4] S. Mardiyati, J. Juliana, and D. Driyani, "Sistem Penunjang Keputusan Pemilihan Perumahan Dengan Menggunakan Metode AHP," Faktor Exacta, vol. 9, pp. 63-71, 2016. http://dx.doi.org/10.30998/faktorexacta.v9i1.742.

[5] R. Lestari, E. Kurniawati, and M. Dizani, "Sistem Pendukung Keputusan Pemilihan Rumah Kostt Di Sekitar Lingkungan Kampus Universitas Serang Raya Menggunakan Metode Analytical Hierarchy Process (AHP)," JSiI (Jurnal Sistem Informasi), vol. 2, pp. 8-12, 2015. https://doi.org/10.30656/jsii.v2i0.61.

[6] A. Y. Saputra and Y. E. Mawartika, "Sistem Pendukung Keputusan Dalam Memilih Perumahan Dengan Metode Simple Multi Attribute Rating Technique," Cogito Smart Journal, vol. 5, pp. 35-44, 2019. http://cogito.unklab.ac.id/index.php/cogito/article/view/149.

[7] H. Dharma, "Aplikasi Penentuan Prioritas Kriterria Pemilihan Rumah Kost Berbasis Analytical Hierarchy Process (AHP)," EXPERT: Jurnal Manajemen Sistem Informasi dan Teknologi, vol. 3, pp. 100-105, 2013. http://dx.doi.org/10.36448/jmsit.v3i2.485.

[8] I. Syafrinal and D. Aldo, "Implementasi Metode Analytical Hierarchy Process (AHP) Untuk Penilaian Rumah Huni," INOVTEK Polbeng-Seri Informatika, vol. 5, pp. 205-217, 2020. https://doi.org/10.35314/isi.v5i2.1263.

[9] B. Hudaya, "Sistem Pendukung Keputusan Kelayakan Penerima Subsidi Kepemilikan Rumah Menggunakan Adaptive Neuro-fuzzy Inference System," STRING (Satuan Tulisan Riset dan Inovasi Teknologi), vol. 3, pp. 324-329, 2019. http://dx.doi.org/10.30998/string.v3i3.3594.

[10] S. Sarwindah and M. Marini, "Sistem Penilaian Kinerja Karyawan PT. Cahaya Iqra Mandiri Menggunakan Metode Analytical Hierarchy Process," ILKOM Jurnal $\begin{array}{lllll}\text { Ilmiah, } & \text { vol. } & 11, & \text { pp. } & 110-117,\end{array}$ http://jurnal.fikom.umi.ac.id/index.php/ILKOM/article/view/433.

[11] R. M. Simanjorang, H. D. Hutahaean, and H. T. Sihotang, "Sistem Pendukung Keputusan Penentuan Penerima Bahan Pangan Bersubsidi Untuk Keluarga Miskin Dengan Metode AHP Pada Kantor Kelurahan Mangga," Journal Of Informatic Pelita Nusantara, vol. 2, pp. 22-31, 2017. http://orcid.org/0000-00023598-4033.

[12] F. Siregar, J. Sisca, N. Aisyah, and R. Rosmawati, "Sistem Pendukung Keputusan Pemilihan Rumah Bersubsidi Dengan Menerapkan Metode Weigthed Aggregated Sum Production Assessment," in Seminar Nasional Sains dan Teknologi Informasi (SENSASI), 2018, pp. 632-637. http://prosiding.seminarid.com/index.php/sensasi/article/view/93.

[13] I. Mahendra and P. K. Putri, "Implementasi Metode Analytical Hierarchy Process (AHP) Dalam Sistem Pendukung Keputusan Pembelian Rumah di Kota Tangerang," Jurnal Teknoinfo, vol. 13, pp. 36-40, 2019. https://doi.org/10.33365/jti.v13i1.238.

[14] H. Ardiyanto, P. S. Sasongko, and S. Adhy, "Sistem Pendukung Keputusan Pemilihan Perumahan Menggunakan Metode AHP Berbasis WEB (Studi Kasus 
CV. Wisma Anungkriya Demak)," Journal of Informatics and Technology, vol. 2, pp. 50-58, 2014. https://ejournal3.undip.ac.id/index.php/joint/article/view/6293.

[15] P. A. Primanda, E. Santoso, and T. Afirianto, "Pemilihan Kost di Sekitar Universitas Brawijaya menggunakan Metode Analitycal Hierarchy Process (AHP) dan Simple Additive Weighting (SAW)," Jurnal Pengembangan Teknologi Informasi dan Ilmu Komputer e-ISSN, vol. 2548, p. 964X, 2018. http://jptiik.ub.ac.id/index.php/j-ptiik/article/view/1616.

[16] M. S. Rais, "Sistem Pendukung Keputusan Untuk Pemilihan Lokasi Perumahan Menggunakan Analytical Hierarchy Process (AHP)," Riau Journal Of Computer Science, vol. $\quad 2, \quad$ pp. 59-72, $2016 . \quad$ https://ejournal.upp.ac.id/index.php/RJOCS/article/view/873.

[17] Z. D. Unutmaz Durmuşoğlu, "Assessment of techno-entrepreneurship projects by using Analytical Hierarchy Process (AHP)," Technology in Society, vol. 54, pp. 4146, 2018. https://doi.org/10.1016/j.techsoc.2018.02.001.

[18] T. L. Saaty, "Decision making with the analytic hierarchy process," International journal of services sciences, vol. 1, pp. 83-98, 2008. https://doi.org/10.1504/IJSSci.2008.01759.

[19] Y. Prihartono and H. Magdalena, "Penerapan Metode Analytical Hierarchy Process (AHP) Sebagai Pendukung Keputusan dalam Menentukan Internet Service Provider Terbaik di Pangkalpinang," Jurnal Sisfokom (Sistem Informasi dan Komputer), vol. 5, pp. 21-32, 2016. https://doi.org/10.32736/sisfokom.v5i1.195. 